\title{
The assessment of knowledge and practical skills of intramuscular injection administration among nursing staff: a cross-sectional study
}

\author{
AUTHORS \\ URŠKA FEKONJA RN ${ }^{1}$ \\ ZVONKA FEKONJA MSC, RN ${ }^{2}$ \\ DOMINIKA VRBNJAK PhD, RN ${ }^{2}$ \\ CORRESPONDING AUTHOR \\ URŠKA FEKONJA University Clinical Centre Maribor, Ljubljanska ulica 5, Maribor, Slovenia 2000. \\ Phone: +386 31443 711. Email: ufekonja@gmail.com or urska.fekonja1@student.um.si
}

\section{ABSTRACT \\ Aim: This study aimed to assess the level of knowledge and practice of intramuscular injection among nurses and nursing assistants in primary healthcare.}

Background: Evidence-based guidelines recommend the use of the ventrogluteal site for intramuscular injection; however, it remains infrequently utilised by nurses.

Study design and methods: Cross-sectional study was conducted using a convenience sample of 200 nurses and nursing assistants employed in one of the largest healthcare centres on the primary healthcare level in Slovenia. The data were collected using a self-reported questionnaire and analysed using descriptive and inferential statistics.

Results: The majority of the participants (88.5\%) prefer to use the dorsogluteal site for intramuscular injections, while the ventrogluteal site is commonly used only by $7.5 \%$ of the respondents. Participants avoid the ventrogluteal site because of not being used to it $(30.5 \%)$, unfamiliarity $(27.0 \%)$, lack of adequate knowledge (19.5\%), fear of harming the patient (8.5\%), and not knowing how to determine the site (10.3\%).

Conclusion: Nursing staffs knowledge and use of ventrogluteal site for intramuscular injection is limited and are using traditional methods instead of current evidence-based guidelines.

Implications: Improvements are needed in nursing education and continuous training. The nurse administrators in clinical practice should increase awareness of the benefits of using evidencebased practice and re-evaluate how the nursing professionals provide the administration of intramuscular injections and the need for additional education. The education and training about intramuscular injections should be implemented regularly in daily clinical practice of nursing professionals for promoting the safest practice for patients.

\section{What is already known about the topic?}

- The administration of intramuscular injections is a commonly performed nursing intervention in clinical practice.

- The technique for delivering intramuscular injection is associated with potential safety risks for the patient when it is not done according to evidencebased guidelines and safe practices.

- The use of ventrogluteal muscle has been recommended in nursing literature for many years now, but nurses still use it infrequently and prefer to use the dorsogluteal site. 
What this paper adds:

- Despite being both legally permitted to administer intramuscular injection, nurses and nursing assistants demonstrated different levels of knowledge and the use of evidence-based recommendations about intramuscular injection administration.

- Nurses avoid using the ventrogluteal side due to lack of knowledge and skills.
- Stronger emphasis on raising awareness about the importance of using evidence-based practices during nursing education and continuous training is needed.

Keywords: Injections, intramuscular; primary healthcare; punctures; evidence-based nursing

\section{INTRODUCTION}

Intramuscular injections (IMI) are important and frequently performed nursing interventions. ${ }^{1,2}$ World Health Organization (WHO) defines IMI as a parenteral, preventive, or curative route of administering the drug into muscle tissue by choice of the appropriate size of a needle. ${ }^{3}$ Although interpreted as simple intervention, it requires critical assessment, skills, and knowledge about choosing the proper site and the safest practice. 4,5 WHO estimates that out of 12 billion injections administered globally every year, 50\% of them are administered unsafely. ${ }^{6}$

IMI can cause various serious complications when evidencebased guidelines and safe practices are not followed. Complications can be a pain, tissue necrosis, abscesses, cellulite, nerve damages, haematoma, granuloma, muscular fibrosis and contracture, infection, vascular or bone injuries and permanent or temporary paralysis of lower extremities. ${ }^{2,5,7-9}$

There are three main muscle groups identified for IMI administration: the deltoid muscle of the upper arm, gluteal muscles of the buttocks that states for dorsogluteal (DG) (gluteus maximus) and ventrogluteal (VG) site (gluteus medius), and quadriceps muscles in the thigh that include rectus femoris and vastus lateralis. ${ }^{10-12}$ The selection of an appropriate site depends on factors, such as the type and the volume of medication, patient's age and health condition. ${ }^{9-11,13}$ Carelessness, inaccuracy, and misperception of appropriate application can cause serious complications. ${ }^{2,5,8,14}$ The most complications occur when the IMI is administered into the DG site, as this area includes a rich intertwining of the vessels, is in the proximity of the sciatic nerve. There is also a thinner layer of subcutaneous tissue. ${ }^{8,15}$ Much of the recent evidence-based literature recommends the use of a VG site, as it is relatively free of large blood vessels, nerves (sciatic nerve) and sealed off by bone; it is also easier to identify, and the layer of subcutaneous tissue there is much thinner than the one on the DG site. Gluteus medius muscle in this site is large and well developed.,16,17 It has been discovered that patients suffered less pain, discomfort, and bleeding when receiving an IMI into the VG site compared to those receiving it into the DG site. The VG site enables faster absorption of the medication and easier as well as better access to the muscle tissue. ${ }^{18}$

Although the use of VG muscle has been recommended, nurses still use it infrequently, due to the fact they instead rely on the traditional approach of IMI administration preferring DG site. ${ }^{12,18-20}$ It is crucial to continuously determine the level of knowledge and the use of evidencebased recommendations about IMI administration among nurses to develop effective education and training. ${ }^{16}$

Our study aimed to assess the level of knowledge and practical skills in the area of IMI among nursing staff working in one of the largest healthcare centres in Slovenia.

\section{METHOD}

\section{RESEARCH DESIGN AND SETTING}

A cross-sectional study was conducted in one of the largest healthcare centres in Slovenia. Health Centre provides primary healthcare and includes general or family medicine clinics, outpatient clinics for preschool and school children, gynaecologist outpatient clinics, emergency service, dental clinics, and community nursing services, clinics of occupational, traffic and sports medicine, clinical laboratories, radiology services, and some specialist clinics. The number of employed healthcare professionals at the time this research was carried out was approximately 197 physicians, 211 nurses and 186 nursing assistants. ${ }^{21}$

\section{SAMPLE}

Convenience sampling was used for recruiting nurses and nursing assistants. All nurses and nursing assistants who are administering an IMI to adult patients in everyday clinical practice and working at the selected institution in the Department for Family Medicine Clinics, Community Healthcare Centre, Department of Occupational, Traffic and Sports Medicine, or Emergency Service were invited to fill out the anonymous questionnaire $(\mathrm{N}=267)$. The 212 questionnaires were returned after two reminders, giving an overall response rate of 79.4\%. Twelve questionnaires were 
excluded due to missing data, resulting in a total sample of 200.

In Slovenia, the nursing education system consists of a minimum four year secondary education (for nursing assistants), three years of the first cycle Bologna higher education (for nurses with a diploma degree), two years of the second cycle Bologna higher education (for nurses with a master's degree) and three years of third cycle Bologna higher education (for nurses with a PhD). ${ }^{22}$ Nursing assistants are trained in providing basic nursing care and also have competencies for medication administration (per os, intramuscular and subcutaneous therapy). ${ }^{23}$ Nurses are independent experts who are responsible for nursing care and independently and autonomously perform nursing procedures and interventions in the nursing process. ${ }^{22,23}$ The current study included 65 nursing assistants (32.5\%) and 135 nurses $(67.5 \%)$.

\section{INSTRUMENT}

Data were collected using a self-reported questionnaire, which was developed based on a comprehensive literature review on nurses' knowledge and experiences about the IMI. ${ }^{15,16,19,20,24}$ The questionnaire consisted of 46 questions on nurses' demographic, knowledge and experiences about the IMI and was divided into five sections.

The first section included four questions on participants demographic characteristics (gender, educational status, working service, years of experience).

The second section included three questions with multiple choice questions regarding daily frequency of administering IMI, most frequently used site for IMI and knowledge on the site recommended in the latest literature.

The third section included three questions about education and practice concerning the VG site. Participants have been offered multiple-choice questions.

The fourth section included 19 questions regarding participants habits in their daily clinical practice on IMI. The frequency (never, sometimes, always) of performing specific steps to perform an IMI was evaluated (eg. checking the dose and the date of the medication, the use of gloves, Z-track method, two-needle technique, aspiration technique before administration, considering injection site, weight and size of the patient, the use of different needle sizes, controlling patient's response on medication).

The fifth section included 16 questions related to participants theoretical and practical knowledge of IMI. Seven statements were prepared as correct and nine as incorrect, and the participants were asked to respond to these statements with the options "true", "false" or "do not know". Each correct answer was considered as 1 point, while wrong or "do not know" responses were considered as o points. The minimum score was o points, and the maximum score was
16, with higher scores indicating better knowledge about IMI administration.

The draft instrument was pilot tested with 10 nurses to evaluate the feasibility of the questionnaire as well as face validity. No further revisions of the questionnaire were identified.

\section{DATA COLLECTION}

The data were collected between May and early July 2019. The selected institution gave written permission for the research. No approval from an ethics committee was required because no patients or interventions were involved. Questionnaires were given out with the assistance of head nurses of each department in a paper form. The completed questionnaires were returned in a sealed envelope.

\section{DATA ANALYSIS}

Data were analysed using the IBM Statistical Package for the Social Sciences (SPSS) program for Windows (version 27.0). Descriptive statistical methods were employed for descriptions of respondents' demographic characteristics and items scores knowledge (average, standard deviation, percentage), Mann-Whitney U, and Kruskal-Wallis one-way analysis of variance tests. A probability level of 0.05 or less was used to indicate statistical significance.

\section{RESULTS}

Out of 267 distributed questionnaires, 212 were returned, and 200 included in the analysis (74.9\% realisation). The detailed demographic characteristics are presented in Table 1.

The total average score relating level of knowledge was $5.0 \pm 3.020$ (points ranging of o-16). Statistical significance was found between working service and educational level $(\mathrm{p}<0.05)$. Participants working in emergency service and participants who had post-graduate degrees had higher average scores (Table 1 ).

99.5\% of participants reported they administer up to nine IMI per day. From Table 2, it can be seen that the majority of participants $(41.5 \%, \mathrm{n}=83$ ) said DG site is recommended site in the latest literature. While the third $(36.5 \%, n=73)$ of the participants were aware that the VG site is currently evidencebased recommendation, the most frequently used site for IMI remains DG $(88.5 \%, n=177)$, VG site is commonly used only by $7.5 \%$ of participants $(n=15)$. Some individuals reported that they most frequently use deltoid muscle $(2.0 \%, n=4)$ or the vastus lateralis and rectus femoris muscles $(1.0 \%, \mathrm{n}=2)$. $15.5 \%(n=31)$ participants reported they do not know what the recommended site is in the latest literature (Table 2).

When asked whether participants received any courses about administering IMI into the VG site, 52 (26.0\%) answered affirmatively. Others, 148 (74.0\%) were not trained or educated on current evidence-based guidelines either in secondary 
or higher education. Sixty one (30.5\%) participants were not used to the VG site and therefore avoid it. Other reasons that discouraged participants from selecting the VG site for IMI were unfimilarity $(27.0 \%, n=55)$, lack of adequate knowledge $(19.5 \%, \mathrm{n}=39)$ and do not know how to determine the VG site $(10.5 \%, n=21)$. All these factors could be related to the fear of harming the patient, which was selected by 17 (8.5\%) respondents. Statistical significance between nurses and nursing assistants was found for questions related to education about the VG site during studying $(\mathrm{p}<0.005)$

(Table 3 ).

TABLE 1: PARTICIPANTS' CHARACTERISTICS AND LEVEL OF KNOWLEDGE OF INTRAMUSCULAR INJECTION

\begin{tabular}{|c|c|c|c|c|}
\hline Characteristics & $n$ & $\%$ & $\begin{array}{r}\text { Level of } \\
\text { knowledge of } \\
\text { intramuscular } \\
\text { injection }\end{array}$ & $p$ value \\
\hline \multicolumn{5}{|l|}{ Gender $^{\star \star}$} \\
\hline Male & 38 & 19.0 & 5.00 & \multirow[t]{2}{*}{0.921} \\
\hline Female & 162 & 81.0 & 5.01 & \\
\hline \multicolumn{5}{|l|}{ Working service ${ }^{\star \star \star}$} \\
\hline $\begin{array}{l}\text { Department for General } \\
\text { Healthcare Services }\end{array}$ & 89 & 44.5 & 4.53 & \multirow[t]{4}{*}{$0.037^{\star}$} \\
\hline $\begin{array}{l}\text { Community healthcare } \\
\text { centre }\end{array}$ & 53 & 26.5 & 5.32 & \\
\hline $\begin{array}{l}\text { Department of } \\
\text { Occupational, Traffic and } \\
\text { Sports Medicine }\end{array}$ & 12 & 6.0 & 3.50 & \\
\hline Emergency service & 46 & 23.0 & 5.96 & \\
\hline \multicolumn{5}{|l|}{ Educational status ${ }^{\star \star \star}$} \\
\hline $\begin{array}{l}\text { Nursing assistants } \\
\text { (Secondary vocational } \\
\text { education) }\end{array}$ & 65 & 32.5 & 4.12 & \multirow[t]{3}{*}{$0.002^{*}$} \\
\hline Nurses (Diploma degree) & 117 & 58.5 & 5.03 & \\
\hline $\begin{array}{l}\text { Nurses (Postgraduate } \\
\text { degree) }\end{array}$ & 18 & 9.0 & 7.72 & \\
\hline \multicolumn{5}{|c|}{ Experience in nursing since graduation ${ }^{\star \star \star}$} \\
\hline $1-9$ years & 61 & 30.5 & 4.84 & \multirow[t]{5}{*}{0.334} \\
\hline 10-19 years & 56 & 28.0 & 5.50 & \\
\hline 20-29 years & 39 & 19.5 & 4.97 & \\
\hline 30-39 years & 38 & 19.0 & 5.16 & \\
\hline$>40$ years & 6 & 3.0 & 1.33 & \\
\hline \multicolumn{5}{|l|}{ Sources of training ${ }^{\star \star \star}$} \\
\hline Seminar, course, etc. & 87 & 43.5 & 4.69 & \multirow[t]{5}{*}{0.502} \\
\hline Brochure, book, etc. & 22 & 11.0 & 4.41 & \\
\hline By oneself & 23 & 11.5 & 5.70 & \\
\hline From physicians & 6 & 3.0 & 5.31 & \\
\hline From nurses & 62 & 31.0 & 6.00 & \\
\hline
\end{tabular}

$\mathrm{n}=$ number

$\%$ = percentage

* $=$ Significant level at the 0.05 level

** = Mann-Whitney U Test

${ }^{\star * *}=$ Kruskal-Wallis one-way analysis of variance
TABLE 2: FREQUENCY OF USED SITE AND KNOWLEDGE OF RECOMMENDED INTRAMUSCULAR INJECTION SITE

\begin{tabular}{|l|r|r|}
\hline Answer & $n=200$ & $\%$ \\
\hline Most frequently used site & 4 & 2.0 \\
\hline Deltoid muscle & 2 & 1.0 \\
\hline Vastus lateralis and Rectus femoris & 177 & 88.5 \\
\hline DG site & 15 & 7.5 \\
\hline VG site & 2 & 1.0 \\
\hline Missing data & & \\
\hline Site recommended in the latest literature & 83 & 41.5 \\
\hline DG site & 73 & 36.5 \\
\hline VG site & 3 & 1.5 \\
\hline Vastus lateralis & 2 & 1.0 \\
\hline Rectus femoris & 8 & 4.0 \\
\hline Deltoid muscle & 31 & 15.5 \\
\hline Don't know & & \\
\hline
\end{tabular}

TABLE 3: EDUCATION AND PRACTICE CONCERNING THE VENTROGLUTEAL SITE

\begin{tabular}{|l|l|l|l|}
\hline Answer & $\begin{array}{l}\text { Nursing } \\
\text { assistants }\end{array}$ & Nurses & p value \\
\hline Education about the VG site during studying? & \multicolumn{2}{|l}{} \\
\hline Yes & 28 & 24 & $0.000^{*}$ \\
\hline Not received & 37 & 111 & \\
\hline
\end{tabular}

Have you given an IMI to the VG site in your professional career?**

\begin{tabular}{|c|c|c|c|}
\hline Yes & 21 & 36 & \multirow[t]{2}{*}{0.409} \\
\hline No & 44 & 99 & \\
\hline \multicolumn{4}{|l|}{ Reasons for avoiding VG site ${ }^{\star \star \star}$} \\
\hline I am not used to it & 19 & 42 & \multirow[t]{6}{*}{0.101} \\
\hline Lack of adequate knowledge & 6 & 33 & \\
\hline VG site is too small & 0 & 5 & \\
\hline Fear of harming the patient & 8 & 9 & \\
\hline I cannot locate it & 8 & 13 & \\
\hline I am not acquainted with VG site & 22 & 33 & \\
\hline
\end{tabular}

* $=$ Significant level at the 0.05 level

** $=$ Mann-Whitney U Test

${ }^{\star * *}=$ Kruskal-Wallis one-way analysis of variance 
More than half of the participants (59.0\%, $n=118$ ) answered that they take into consideration patient's body mass index (BMI) when selecting the appropriate needle size and injection site $(52.0 \%, \mathrm{n}=104)$. They prefer to use needle size $21 \mathrm{G}(24.0 \%, \mathrm{n}=48$, »always", and $40.0 \%, \mathrm{n}=80$, »rarely" ) in comparison to needle size $23 \mathrm{G}(6.0 \%, \mathrm{n}=3$, "always», and $41.0 \%$, $\mathrm{n}=82$, »rarely"). The two-needle technique was most reported to be used $(78.5 \%, n=157)$. Seventy nine percent $(n=158)$ and participants reported they always wipe the injection site with an antiseptic wipe or alcohol wipe $(97.0 \%, n=194)$ and wait till the antiseptic solution is completely dry before administering $\operatorname{IMI}(67.5 \%, \mathrm{n}=135$ »always" and $28.5 \%, \mathrm{n}=57$ "rarely"). The majority of participants reported "always" to use the technique of aspiration to check the presence of blood before administering prescribed medication (80.0\%, $\mathrm{n}=160$ ). Most were not familiar with Z-track technique and consequently reported they do not use it $(68.5 \%, n=137)$ (Table 4).

Regarding educational status, statistical significance was found for questions related to checking the dose and use-by date before administering medication, considering injection site, weight and size of the patient when selecting needle size before administering the medication, the use of a 23 Gauge needle size, assessing the injection site immediately after administrating the medication, controlling the patient's response and possible side effects, adjust the injection site to the prescribed medication, observing the possible occurrence of side effects to medication, aspiration, administering injection at the dry disinfected area $(\mathrm{p}<0.005)$ (Table 4).

Very few participants were familiar that exercise is recommended after administrating $\operatorname{IMI}(8.0 \%, n=16)$, that VG site is recommended in children over the age of seven months $(12.5 \%, \mathrm{n}=25)$ and that VG site can take up to 4 millilitres of medicine $(15 \cdot 5 \%, n=31)$ (Table 5$)$.

Nurses expressed a higher level of knowledge of administering an IMI to the VG site when compared to nursing assistants. Statistical significance was found in questions related to the speed of administrating IMI (quickly, in few seconds), occurring complications in the VG site (damaging sciatic nerve), volume (up to $4 \mathrm{ml}$ of medication), determining injection site (place nurse's left hand on the patient's right hip and palpating bone structures in the VG site $)(\mathrm{p}<0.005)$.

TABLE 4: NURSES' PRACTICE ON INTRAMUSCULAR INJECTION IN THEIR DAILY CLINICAL PRACTICE

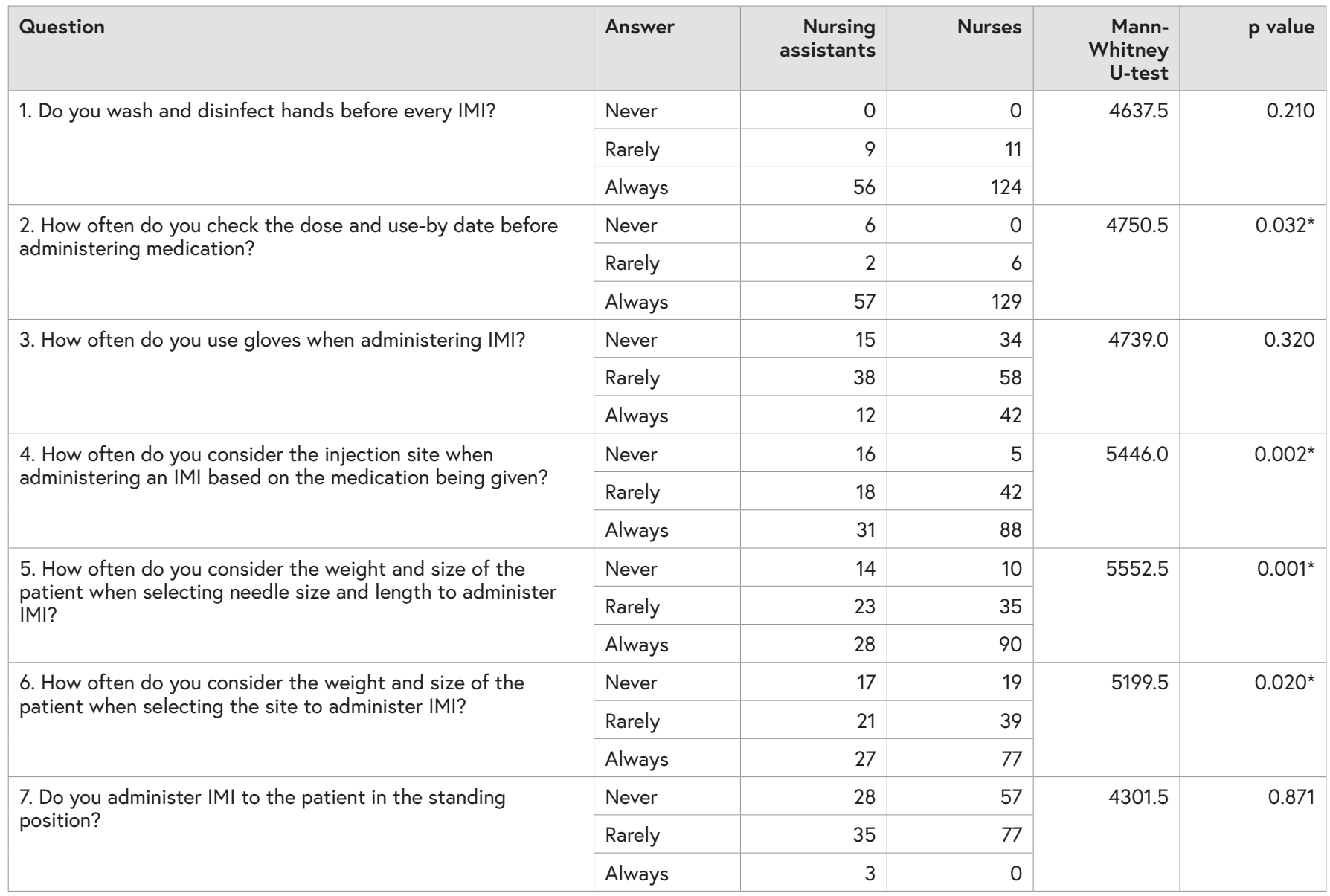


TABLE 4: NURSES' PRACTICE ON INTRAMUSCULAR INJECTION IN THEIR DAILY CLINICAL PRACTICE (CONTINUED)

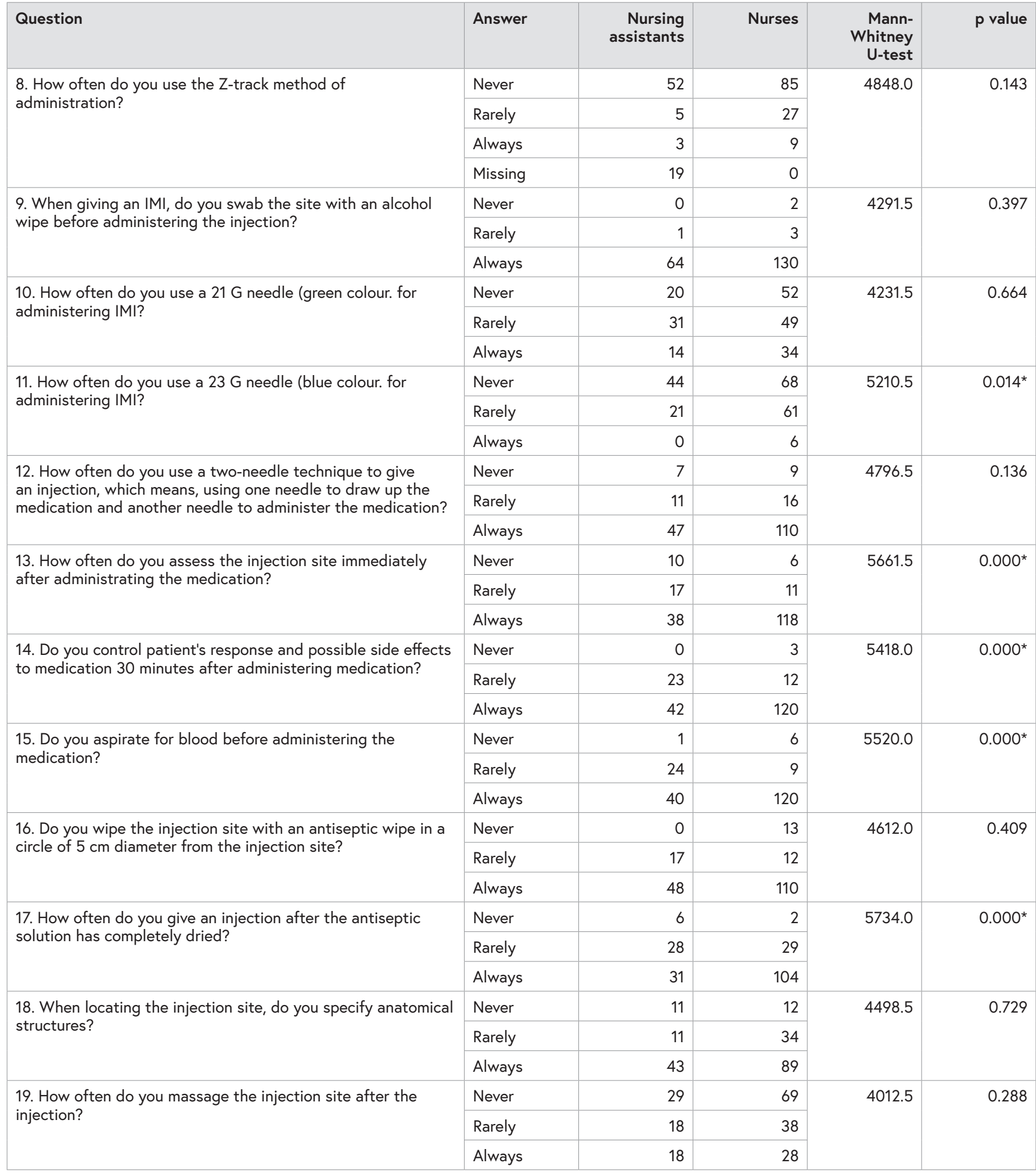

* = Significant level at the 0.05 level 
TABLE 5: KNOWLEDGE OF ADMINISTERING AN INTRAMUSCULAR INJECTION TO VENTROGLUTEAL SITE

\begin{tabular}{|c|c|c|c|c|c|}
\hline Question & $\begin{array}{l}\text { Correct } \\
\text { answer }\end{array}$ & $\begin{array}{r}\text { Nursing } \\
\text { Assistants }\end{array}$ & Nurses & $\begin{array}{r}\text { Mann- } \\
\text { Whitney } \\
\text { Test }\end{array}$ & $\mathrm{p}$ value \\
\hline $\begin{array}{l}\text { 1. Injection to the VG site may be difficult in very overweight } \\
\text { patients because the greater trochanter cannot be found. }\end{array}$ & True & 23 & 44 & 4195.0 & 0.573 \\
\hline $\begin{array}{l}\text { 2. The tissue at the injection site is bunched between the } \\
\text { thumb and the forefinger. }\end{array}$ & False & 22 & 29 & 3782.5 & 0.054 \\
\hline 4. After administrating IMI it is recommended to exercise. & True & 11 & 5 & 4716.5 & 0.260 \\
\hline $\begin{array}{l}\text { 5. IMI is safer at the VG site since it is away from large blood } \\
\text { vessels and nerves. }\end{array}$ & True & 25 & 69 & 3863.5 & 0.128 \\
\hline $\begin{array}{l}\text { 6. The most common complication in the VG site is damaging } \\
\text { the sciatic nerve. }\end{array}$ & False & 6 & 60 & 5234.0 & $0.019^{*}$ \\
\hline $\begin{array}{l}\text { 7. Complications, such as pain, infection, necrosis, nerve } \\
\text { damage, fibrosis, do not occur at the VG site. }\end{array}$ & True & 8 & 53 & 3310.5 & $0.002^{*}$ \\
\hline $\begin{array}{l}\text { 8. VG site is not recommended for injecting oily solutions or } \\
\text { irritants. }\end{array}$ & False & 18 & 16 & 4369.0 & 0.951 \\
\hline $\begin{array}{l}\text { 9. It is harder to reach the muscle tissue at the VG site } \\
\text { because of the thickness of the subcutaneous layer. }\end{array}$ & False & 11 & 45 & 4323.5 & 0.855 \\
\hline 10. VG site can take up to 4 millilitres of medicine. & True & 4 & 27 & 3213.0 & $0.000^{*}$ \\
\hline $\begin{array}{l}\text { 11. In order to determine the injection site, the nurse has to } \\
\text { place her right hand on the patient's right hip. }\end{array}$ & False & 16 & 28 & 3457.5 & $0.009^{*}$ \\
\hline $\begin{array}{l}\text { 12. The VG site is palpated using imaginary lines, DG site by } \\
\text { the use of bone structure. }\end{array}$ & False & 15 & 31 & 3089.0 & $0.000^{*}$ \\
\hline $\begin{array}{l}\text { 13. Patients are advised to lay on their back or on the right/ } \\
\text { left side. }\end{array}$ & True & 30 & 76 & 3874.5 & 0.135 \\
\hline $\begin{array}{l}\text { 14. Use of the VG site is recommended in children over the age } \\
\text { of seven months. }\end{array}$ & True & 11 & 14 & 4154.5 & 0.435 \\
\hline 16. The risk of contamination is very high at the VG site. & False & 11 & 74 & 4055.0 & 0.341 \\
\hline
\end{tabular}

* $=$ Significant level of $p<0.05$

\section{DISCUSSION}

We found that participants' knowledge about evidencebased recommendations regarding IMI administration is limited. Nurses with a post-graduate degree working in emergency service reported the highest level of knowledge. Differences in education between nursing assistants, nurses with diploma degree and post-graduate degree may account for the findings. Although Bajracharya found the level of education had no statistically significant relationship between knowledge and practice regarding IMI, ${ }^{25}$ it was later found to influence the selection of the VG site for administering IMIs. ${ }^{18}$ Nurses with a post-graduate degree also tend to have better knowledge and attitudes towards evidence-based practice. ${ }^{26}$ In Slovenia, most subjects or modules on evidence-based practice are offered in master's nursing programmes. ${ }^{27}$ Findings could also be influenced by the frequency of administered IMIs. In the emergency service, IMIs are frequently administered, especially for pain relief, or even for faster therapeutic results. ${ }^{28}$ From 12,594 IMIs administered in a selected healthcare centre in 2019, most were administered in the emergency service.
Although the VG site for IMI is suggested in evidence-based nursing literature, the DG site was the most common choice for application of IMI. Others report similar results. ${ }^{16,18,20,29}$ Most also reported the DG site is recommended in the latest literature; almost one-tenth did not know what the recommended site is. It seems nursing staff did not get adequate education and have therefore rarely administered IMI to the VG site. Almost three-quarters of participants reported they did not receive education about the VG site during their studies. According to Floyd and Meyer, ${ }^{29}$ the theory about injections into the VG site are taught in some nursing schools. Our findings suggest the opposite, and there is a need to evaluate curriculums not only at secondary vocational education level but also in higher education to confirm these findings. Despite the more significant percentage not receiving education, nurses expressed better knowledge about site determination, complications concerning site selection, speed and volume of IMI when compared to nursing assistants. However, nurses' knowledge about volume VG can take and appropriateness to use the VG site in children also was limited. Nurses have also expressed better adherence to current guidelines and knowledge of 
administering an IMI when compared to nursing assistants. It could be they receive education and training on IMI and other skills, as well as biology, anatomy, pathophysiology, and pharmacological theory when nursing assistants receive more limited theoretical education. ${ }^{30,31}$ Further research is therefore needed to evaluate nursing student's knowledge and practice on evidence-based recommendations concerning IMI. Emphasis should not only be placed on theoretical education but also clinical training and clinical mentors. Some suggest nursing students rarely have the opportunity to observe the application of IMIs into the VG site in clinical practice. ${ }^{29}$ The level of knowledge could also decrease if not used constantly in clinical practice.

We found that nursing staff, although being informed about the VG site, avoid using it mostly as they are not used to it, followed by not being acquainted with it, and not having enough knowledge. A few have also expressed fear of harming the patient when administering an IMI to the VG site. Not used to giving injections at the VG site was also reported as the main reason for not using it by Turkish nurses working in hospitals. ${ }^{19}$ Others have listed other possible reasons for avoiding the VG site, such as age of nurses, ${ }^{8}$ insufficient knowledge about the advantages of using the VG site, small surface area for injection, lack of confidence, ${ }^{14,16,32}$ and concern about harming the patients. ${ }^{33}$ Further studies in Slovenia should evaluate whether there are some factors that influence possible reasons for avoiding the VG site.

When evaluating daily clinical practice, most participants reported adherence to hand hygiene in terms of washing and disinfecting as well as to disinfect the injection site. Findings are not surprising, as there is a strong emphasis on five moments for hand hygiene and preventing infections not only in education but also in clinical practice. ${ }^{34}$ What is concerning, is the poor practice of wearing gloves when administering IMI. Findings are in contrast to the results, where a vast majority of participants reported they often or always wear gloves. $35,3^{6}$ Nursing assistants also do not allow the skin to dry during the process of disinfection of the injection site. Further research is needed to determine the reasons for this poor practice, not only quantitative but also qualitative research. For more than two decades nursing students in Slovenia have been educated on using gloves and the disinfection process when administering IMI. ${ }^{37}$ Nurses and nursing assistants are also working in accordance with the same institutional standards, and standards in a healthcare centre are in line with international recommendations which suggests wearing gloves,,$^{38}$ even though WHO recommended not to use gloves for routine IMI. ${ }^{39}$ Nonetheless, nursing standards in all healthcare institutions should be reviewed to determine if institutions have different standards and whether they are following current recommendations.
Also, several other practices are not in line with evidencebased recommendations. More than half of the participants in this research always consider the BMI of patients when choosing the needle size, its length and the injection site. A tenth of participants have never adjusted the needle size or choice of the injection site to the patient's gender, weight or BMI, thus increasing the risk of administering the IMI to the subcutaneous tissue or outside the muscle tissue..$^{32}$ When locating the injection site, only two-thirds of our participants have specified anatomical structures.

On the other hand, the majority of participants have reported consistent use of the aspiration technique to check the presence of blood before administering the prescribed medication. However, more recent recommendations from WHO and the Centers for Disease Control and Prevention's (CDC) report, the practice of aspiration during IMIs is premature and is expected to be eliminated. Aspiration only makes sense in areas with large vascular structure, such as the DG site. ${ }^{11}$ If nurses succeeded in completely eradicating the use of the DG site as the chosen site for IMI, aspiration could be removed from routine nursing care. ${ }^{7}$

Also, the two-needle technique was well respected by participants. We have found that three-quarters of participants regularly use the two-needle technique, $13.5 \%$ use it occasionally, and $8 \%$ never, which is similar to other research. ${ }^{20,40,41}$ The two-needle technique seems to be firmly rooted in our nursing practice. Probably as in rare specific medical areas, pre-filled syringes are not common. Also, nurse educators put a strong emphasis on using the twoneedle technique, when IMI of drug includes preparing and administering medication. ${ }^{37}$

Nurses and nursing assistants reported they are not familiar with the Z-track method and therefore never or rarely use it, which is similar to other findings. ${ }^{24,36,40}$ Although Z-track method is more commonly used in psychiatry, ${ }^{42}$ it is recognised as the most appropriate technique for IMI. ${ }^{36}$ Most probable reason for unfamiliarity is the lack of knowledge as this technique is not included in nursing textbooks.

\section{LIMITATIONS}

The main limitation of this study is sampling. The generalisation of the results is limited due to convenience sampling. The data have been gathered only in one healthcare centre, so they may not apply to other healthcare centres. The analysis of non-respondents was not conducted as their answers were not collected. Social desirability should also be taken into consideration. 


\section{CONCLUSIONS AND IMPLICATIONS FOR NURSING}

Despite the limitations, the study shows that nurses and nursing assistants most frequently use the DG site, do not follow evidence-based recommendations and work on the traditional methods learnt from older colleagues due to a lack of knowledge and skills.

Results of this study could help nurse educators and nurse managers to increase awareness of the benefits of using the evidence-based practice guidelines of using the VG site. It is recommended to ensure adequate theoretical and practical education and training for nursing students, as well as proper training of nurses already working in clinical practice and especially for clinical mentors. Students are continually learning on clinical placements, not only from their clinical mentors. Only by that, can we provide a safer and more efficient delivery of medication into the muscle. Additional studies are needed to determine the level of knowledge and practice among all nursing students and all other nursing employees in primary, secondary, and tertiary healthcare organisations.

Acknowledgments: The authors acknowledge K Petko for their grammatical review of the manuscript.

Funding support: The study received no funding.

Conflict of interest: The authors declare no conflict of interest.

Ethical approval: The study was approved by the Committee for Ethical Approvals in Health Care of the Faculty of Health Sciences, University of Maribor 038/2019/1737-2/504.

\section{REFERENCES}

1. Greenway K. Using the ventrogluteal site for intramuscular injection. Nurs Stand. 2004; 18(25): 39-42. Available from: https://doi.org/10.7748/ns2004.03.18.25.39.c3560

2. Kara D, Uzelli D, Karaman D. Using ventrogluteal site in intramuscular injections is a priority or an alternative? Int J Caring Sci. 2015; 8(2): 507-13.

3. Hutin Y, Hauri A, Chiarello L, Catlin M, Stilwell B, Ghebrehiwet $T$, et al. Best infection control practices for intradermal, subcutaneous, and intramuscular needle injections. Bull World Health Organ. 2003; 81(7): 491-500. Available from: https://doi.org/10.1590/S0042-96862003000700007

4. Hdaib MT, Al-Momany SM, Najjar YW. Knowledge level assessment and change among nursing students regarding administering intra-muscular injection at Al-Balqa'a Applied University: an interventional study. Nurse Educ Today. 2015; 35(7): e18-22. Available from: https://doi.org/10.1016/j. nedt.2015.02.012

5. Small SP. Preventing sciatic nerve injury from intramuscular injections: literature review. J Adv Nurs. 2004; 47(3): 287-96. Available from: https://doi.org/10.1111/j.13652648.2004.03092.x
6. Jung Kim H, Hyun Park S. Sciatic nerve injection injury. J Int Med Res. 2014; 42(4): 887-97. Available from: https://doi.org/10.1177/0300060514531924

7. Malkin B. Are techniques used for intramuscular injection based on research evidence? Nurs Times. 2008; 104(50-51): 48-51.

8. Nicoll LH, Hesby A. Intramuscular injection: an integrative research review and guideline for evidence-based practice. Appl Nurs Res. 2002; 15(3): 149-62. Available from: https://doi. org/10.1053/apnr.2002.34142

9. Wynaden D, Landsborough I, McGowan S, Baigmohamad Z, Finn M, Pennebaker D. Best practice guidelines for the administration of intramuscular injections in the mental health setting. Int J Ment Health Nurs. 2006; 15(3): 195-200. Available from: https://doi.org/10.1111/j.1447-0349.2006.00423.x

10. Hunter J. Intramuscular injection techniques. Nurs Stand. 2008; 22(24): 35-40. Available from: https://doi.org/10.7748/ ns2008.02.22.24.35.c6413

11. Ogston-Tuck S. Intramuscular injection technique: an evidencebased approach. Nurs Stand. 2014; 29(4): 52-9. Available from: https://doi.org/10.7748/ns.29.4.52.e9183

12. Ozdemir L, Piotanarciota E, Akay BN, Akyol A. Effect of methylprednisolone injection speed on the perception of intramuscular injection pain. Pain Manag Nurs. 2013; 14(1): 3-10. Available from: https://doi.org/10.1016/j.pmn.2010.03.002

13. Šmitek J. Izbiranje najprimernejših mest za intramuskularno injekcijo [Slovenian]. Obzor Zdrav Neg. 2006; 40(2): 79-85.

14. Tuğrul $E$, Khorshid L. Effect on pain intensity of injection sites and speed of injection associated with intramuscular penicillin. Int J Nurs Pract. 2014; 20(5): 468-74. Available from: https://doi.org/10.1111/ijn.12161

15. Cornwall J. Are nursing students safe when choosing gluteal intramuscular injection locations? Australas Med J. 2011; 4(6): 315-21. Available from: https://doi.org/10.4066/AMJ.2011764

16. Gülnar $E$, Özveren $H$. An evaluation of the effectiveness of a planned training program for nurses on administering intramuscular injections into the ventrogluteal site. Nurse Educ Today. 2016; 36: 360-3. Available from: https://doi.org/10.1016/j.nedt.2015.09.001

17. Zaybak A, Güneș ÜY, Tamsel S, Khorshid L, Eșer I. Does obesity prevent the needle from reaching muscle in intramuscular injections? J Adv Nurs. 2007; 58(6): 552-6. Available from: https://doi.org/10.1111/j.1365-2648.2007.04264.x

18. Walsh L, Brophy K. Staff nurses' sites of choice for administering intramuscular injections to adult patients in the acute care setting. J Adv Nurs. 2011; 67(5): 1034-40. Available from: https://doi.org/10.1111/j.1365-2648.2010.05527.x

19. Sari D, Sahin M, Yasar E, Taskiran N, Telli S. Investigation of Turkish nurses frequency and knowledge of administration of intramuscular injections to the ventrogluteal site: results from questionnaires. Nurse Educ Today. 2017; 56: 47-51. Available from: https://doi.org/10.1016/j.nedt.2017.06.005

20. Wynaden D, Tohotoa J, Al Omari O, Happell B, Heslop K, Barr L, et al. Administering intramuscular injections: how does research translate into practice over time in the mental health setting? Nurse Educ Today. 2015; 35(4): 620-4. Available from: https://doi.org/10.1016/j.nedt.2014.12.008

21. Završnik J. Zdravstveni dom dr. Adolfa Drolca Maribor: Letno poročilo 2018. Maribor: Zdravstveni dom dr. Adolfa Drolca; 2018. 
22. Pajnkihar M, Štiglic G, Vrbnjak D. The concept of Watson's carative factors in nursing and their (dis)harmony with patient satisfaction. PeerJ. 2017; 5: e2940. Available from: https://doi.org/10.7717/peerj.2940

23. Ažman M, Prestor, J, editors. Poklicne kompetence in aktivnosti izvajalcev $\vee$ dejavnosti zdravstvene nege. Ljubljana: Zbornica zdravstvene in babiške nege Slovenije - Zveza strokovnih društev medicinskih sester, babic in zdravstvenih tehnikov Slovenije; 2019.

24. Carter-Templeton H, McCoy T. Are we on the same page?: a comparison of intramuscular injection explanations in nursing fundamental texts. Medsurg Nurs. 2008; 17(4): 237-40.

25. Bajracharya R. Factors associated with safe intramuscular injection practice among nurses of a teaching hospital. JPAHS. 2019; 6(2): 70-4. Available from: https://doi.org/10.3126/jpahs. v6i2.27235

26. Belowska J, Panczyk M, Zarzeka A, Iwanow L, Cieslak I, Gotlib $J$, et al. Promoting evidence-based practice - perceived knowledge, behaviours and attitudes of Polish nurses: a crosssectional validation study. Int J Occup Saf Ergon. 2020; 26(2): 397-405. Available from: https://doi.org/10.1080/10803548.20 18.1489993

27. Skela-Savič B, Gotlib J, Panczyk M, Patelarou AE, Bole U, RamosMorcillo AJ, et al. Teaching evidence-based practice (EBP) in nursing curricula in six European countries-A descriptive study. Nurs Educ Today. 2020; 94: 104561. Available from: https://doi.org/10.1016/j.nedt.2020.104561

28. Boyd AE, DeFord LL, Mares JE, Leary CC, Garris JL, Dagohoy $\mathrm{CG}$, et al. Improving the success rate of gluteal intramuscular injections. Pancreas. 2013; 42(5): 878-82. Available from: https://doi.org/10.1097/MPA.0b013e318279d552

29. Floyd S, Meyer A. Intramuscular injections: what's best practice? Nurs N Z. 2007; 13(6): 20-2.

30. Strohfus PK, Kim SC, Palma S, Russell AD, Remington R, Roberts C. Immunisations challenge healthcare personnel and affects immunisation rates. App/ Nurs Res. 2017; 33: 131-7. Available from: https://doi.org/10.1016/j.apnr.2016.11.005

31. Strohfus PK, Paugh $O$, Tindell CA, et al. Evidence calls for practice change in intramuscular injection techniques. J Nurs Educ. 2017; 8: 83.

32. Gokbel KY, Midilli TS. Do nurses use the ventrogluteal site in administering intramuscular injections? A pilot study. IOSR-JNHS. 2017; 6(5): 37-42. Available from: https://doi.org/10.9790/1959-0605033742

33. Arslan GG, Özden D. Creating a change in the use of ventrogluteal site for intramuscular injection. Patient Prefer Adherence. 2018; 12: 1749. Available from: https://doi.org/10.2147/PPA.S168885

34. Veliu S, Vrbnjak D, Kaučič Damevska G, Kropfl J. Role of health care professionals in prevention of hospital-acquired infections caused by Carbapenemase resistant bacteria: proactive approach S in General Hospital Ptuj. AJTES. 2019; 3(2): 461-8. Available from: https://doi.org/10.32391/ajtes.v3i2.49

35. Parmeggiani C, Abbate R, Marinelli P, Angelillo IF. Healthcare workers and health care-associated infections: knowledge, attitudes, and behavior in emergency departments in Italy. BMC Infect Dis. 2010; 10: 35. Available from: https://doi.org/10.1186/1471-2334-10-35
36. Legrand G, Guiguet-Auclair C, Viennet H, et al. Nurses' practices in the preparation and administration of intramuscular injections in mental health: a cross-sectional study. J Clin Nurs. 2019; 28(17-18): 3310-7. Available from: https://doi.org/10.1111/jocn.14909

37. Železnik D, Ivanuša A, Železnik P, Brumec V, Lednik L. Standard aktivnosti zdravstvene nege. Maribor: Visoka zdravstvena šola, 2002.

38. Dougherty L, Lister S. The Royal Marsden manual of clinical nursing procedures. Chichester; Hoboken, NJ: Wiley Blackwell; 2015.

39. World Health Organization. WHO best practices for injections and related procedures toolkit. Geneva: World Health Organization; 2010

40. Šakić B, Milutinović D, Simin D. An assessment of intramuscular injection practices among nursing students and nurses in hospital settings: is it evidence-based? SEEJPH. 2012; 2(2): 114-21.

41. Engstrom JL, Giglio NN, Takacs SM, Ellis MC, Cberwenka DI. Procedures used to prepare and administer intramuscular injections: a study of infertility nurses. J Obstet Gynecol Neonatal Nurs. 2000; 29(2): 159-68. Available from: https://doi.org/10.1111/j.1552-6909.2000.tb02036.x

42. Wynaden D, Landsborough I, Chapman R, McGowan S, Lapsley J, Finn M. Establishing best practice guidelines for administration of intramuscular injections in the adult: a systematic review of the literature. Contemp Nurse. 2005; 20(2): 267-77. Available from: https://doi.org/10.5172/ conu.20.2.267 